\title{
Identity and a Model of Investment in Applied Linguistics
}

\author{
RON DARVIN AND BONNY NORTON \\ University of British Columbia \\ ron.darvin@alumni.ubc.ca; bonny.norton@ubc.ca
}

ABSTRACT

This article locates Norton's foundational work on identity and investment within the social turn of applied linguistics. It discusses its historical impetus and theoretical anchors, and it illustrates how these ideas have been taken up in recent scholarship. In response to the demands of the new world order, spurred by technology and characterized by mobility, it proposes a comprehensive model of investment, which occurs at the intersection of identity, ideology, and capital. The model recognizes that the spaces in which language acquisition and socialization take place have become increasingly deterritorialized and unbounded, and the systemic patterns of control more invisible. This calls for new questions, analyses, and theories of identity. The model addresses the needs of learners who navigate their way through online and offline contexts and perform identities that have become more fluid and complex. As such, it proposes a more comprehensive and critical examination of the relationship between identity, investment, and language learning. Drawing on two case studies of a female language learner in rural Uganda and a male language learner in urban Canada, the model illustrates how structure and agency, operating across time and space, can accord or refuse learners the power to speak.

\section{INTRODUCTION}

Exactly two decades ago, in 1995, Bonny Norton began publishing her research on identity, investment, and imagined communities (Norton Peirce, 1995; Norton, 2000, 2013), which is now considered foundational in applied linguistics (Block, 2007; Kramsch, 2013; Miller \& Kubota, 2013; Ortega, 2009; Swain \& Deters, 2007). She has continued to enrich and refine these ideas, working actively with a diverse range of scholars (Darvin \& Norton, 2014b; De Costa \& Norton, forthcoming; Kanno \& Norton, 2003; Norton \& Early, 2011; Norton \& McKinney, 2011; Norton \& Toohey, 2011; Pavlenko \& Norton, 2007). Norton defines identity as "how a person understands his or her relationship to the world, how that relationship is structured across time and space, and how the person understands possibilities for the future" (Norton, 2013, p. 45). Drawing on Weedon's (1987) notion of subjectivity, she shares the poststructuralist's assertion that language constructs our sense of self, and that identity is multiple, changing, and a site of struggle. By theorizing the complex relationship between the language learner and the social world, she seeks to sharpen the lens through which second language acquisition (SLA) scholarship examines the relations of power associated with the 
language learning process. This lens challenges educational agents to reflect on the material conditions that allow learning to take place, and how learners, inscribed by race, ethnicity, gender, social class, and sexual orientation are accorded or refused the right to speak.

Conceptualized as a sociological complement to the psychological construct of motivation (Dörnyei \& Ushioda, 2009; Murray, Gao, \& Lamb, 2011), investment holds a significant place in language learning theory for demonstrating the socially and historically constructed relationship between language learner identity and learning commitment. Kramsch (2013, p. 195) notes as follows:

Norton's notion of investment ... accentuates the role of human agency and identity in engaging with the task at hand, in accumulating economic and symbolic capital, in having stakes in the endeavor and in persevering in that endeavor.

As Norton has argued, if learners invest in a language, they do so with the understanding that they will acquire a wider range of symbolic and material resources, which will in turn increase the value of their cultural capital and social power. Inspired by the work of Bourdieu (1977, 1984, 1991), the construct of investment seeks to collapse the dichotomies associated with traditional conceptions of learner identity (good/bad, motivated/unmotivated, anxious/confident, introvert/extrovert) and recognizes that the conditions of power in different learning contexts can position the learners in multiple and often unequal ways, leading to varying learning outcomes. While constructs of motivation frequently view the individual as having a unitary and coherent identity with specific character traits, investment regards the learner as a social being with a complex identity that changes across time and space and is reproduced in social interaction. In addition to asking, "Are students motivated to learn a language?" one asks, "Are students and teachers invested in the language and literacy practices of a given classroom and community?" For example, a student may be a highly motivated learner, but may not be invested in the language practices of a given classroom if the practices are racist, sexist, or homophobic. As identity is fluid, multiple, and a site of struggle, how learners are able to invest in a target language is contingent on the dynamic negotiation of power in different fields, and thus investment is complex, contradictory, and in a state of flux (Norton, 2013; Norton Peirce, 1995).

Given the considerable interest in the construct of investment by applied linguistics scholars, this article has three objectives. First, we illustrate the diverse ways in which scholars internationally have been drawing on the construct of investment in their identity research, with a focus on more recent scholarship; second, given the social and economic changes that have taken place since the construct was first developed two decades ago, we draw on theoretical advances to propose a model of investment that integrates identity, ideology, and capital; third, we draw on two comparative research studies to illustrate the ways in which the model might serve as a framework for analysis in language learning and applied linguistics. 
Earlier research that drew on Norton's constructs of identity and investment was focused on language learning research in the North American context and focused on the learner and the learning context. Thus McKay and Wong (1996), for example, drew on investment to explain the English language development of four Mandarin-speaking secondary students in a California school; SkiltonSylvester (2002) examined the investments of four Cambodian women in adult English as a second language (ESL) classes in the United States; Potowski (2004) and Bearse and de Jong (2008) focused on investment in the context of two-way Spanish-English immersion programs; and Haneda (2005) drew on the construct of investment to understand the engagement of two university students in an advanced Japanese literacy course. In 2004, Pittaway (2004) provided a helpful literature review on investment research at that time, and by 2006, Cummins argued that investment had emerged as a "significant explanatory construct" (2006, p. 59) in the second language learning literature, using the construct to develop the notion of "identity texts," explored in greater depth in Cummins \& Early (2010).

In more recent years, while scholars in the global North remain committed to identity research, with monographs in abundance (e.g., Block, 2014; Clark, 2009; Higgins, 2011; Kamada, 2010; Kramsch, 2009; Menard-Warwick, 2009; Mercer \& Williams, 2014; Norton, 2013; Preece, forthcoming), interest in the construct of investment, more specifically, has been taken up in widely dispersed regions of the world. In 2008, for example, Arkoudis and Davison (2008) devoted a special issue of the Journal of Asian Pacific Communication to the construct of investment, examining Chinese students' social, cognitive, and linguistic investment in English medium interaction. Articles addressed a wide range of issues, including the investments of college students from nonurban areas in China $(\mathrm{Gu}$, 2008), to the relationship between content and English language interaction in the undergraduate classroom (Trent, 2008), and the use of an "English Club" to practice English by mainland Chinese students in Hong Kong (Gao, Cheng, \& Kelly, 2008). Norton and Gao (2008) provided a comprehensive analysis of the research studies in the special issue, noting that identity and investment are paramount considerations in understanding Chinese learners of English, whether they are in China or other regions of the world. In a study of Jenny, a Chinese language learner in Singapore, for example, De Costa (2010) found the construct of investment highly productive, drawing on investment to better understand how and why Jenny embraced standard English to inhabit an identity associated with being an academically able student. Two central questions, which are increasingly debated in the wider applied linguistics community, are "Who owns English?" and "What are learner and teacher investments in the English language?" With reference to Chinese learners in particular, Norton and Gao noted:

As Chinese learners of English continue to take greater ownership of the English language, redefine the target language community, and develop unique forms of intercultural competence, scholars interested in English language learning and teaching 
need to reframe their research questions and reconsider their assumptions. (Norton \& Gao, 2008, p. 119)

Beyond the North American and Asian context, Norton and her colleagues have been working for over a decade in the African context, and Uganda in particular, to better understand student and teacher investments in digital literacy and the English language (Early \& Norton, 2014; Mutonyi \& Norton, 2007; Norton \& Early, 2011; Norton, Jones, \& Ahimbisibwe, 2011; Norton \& Williams, 2012; Tembe \& Norton, 2008). What they have found is that both Ugandan students and their teachers are highly invested in new literacy practices because digital technology has expanded what is socially imaginable for learners and teachers, extending the range of identities available to community members. Advanced education, professional opportunities, study abroad, and other opportunities have become part of imagined futures and imagined identities. While Norton and her colleagues do not suggest that what is socially imaginable is also socially available in the African context, it was clear that as students and teachers developed valued digital skills, they also gained increasing cultural capital and social power. The investments of female teachers in particular were profound, with one teacher named Betty noting that she "felt like a man" when using a digital camera:

I feel very powerful like a man because I had never held a camera in my life. I have always seen only men carrying cameras and taking photos in big public functions like may be independence celebration, political rallies and wedding ceremonies. But now as I move in the community taking pictures with my camera, I feel I am also very powerful, like a man. (Andema, 2014, p. 91)

Further, while the work of Blommaert (2010) has been particularly helpful in theorizing digital resources as "placed resources," Norton and Williams (2012) have sought to extend his notion of "uptake" with reference to the construct of investment. While Blommaert has argued that discourses shift their value, meaning, and function as they travel across borders, largely as a result of "dominant indexical frames and hierarchies" (Blommaert, 2003, p. 616), Norton and Williams have argued that the construct of investment extends the notion of uptake, given that investment indexes issues of identity and imagined futures.

Emerging scholars in both the global South and North have brought much energy to the study of identity and investment. In Australia, for example, Ollerhead (2012) has drawn on the constructs of investment and imagined communities to understand teacher responses to learner identity in low-level adult ESL classrooms, illustrating how learners' hopes for the future are integral to learner identity. In Brazil, Carazzai and Sanches Silva, like Reeves (2009), have turned their attention to the investments of language teachers rather than language learners. In their doctoral dissertations, Carazzai (2013) and Sanches Silva (2013) studied the construction of teacher identity in the states of Santa Catarina and Mato Grasso $\mathrm{du}$ Sul, focusing on investments in learning and teaching English in a context where Portuguese is the dominant language. They found that investments in the 
English language and the teaching of English are best explained in terms of student teachers' imagined identities, as well as the opportunities afforded to them for both face-to-face and virtual interaction with English speakers internationally. Mastrella-de-Andrade, likewise, has helped to extend theories of identity and investment to her Portuguese-speaking colleagues in Brazil (Mastrella-de-Andrade \& Norton, 2011). In an intriguing mirror image, Anya (forthcoming), although at the time a graduate student in the United States, conducted data collection in Brazil, where she studied the investments of African American language learners of Portuguese in a study abroad program in the Afro-Brazilian city of Salvador. Findings illustrate how African Americans co-constructed and negotiated multiple racialized, gendered, and classed identities in the learning of Portuguese, and how their investments influenced SLA. In what could be described as a "meta study," Chang (2011) has examined the graduate student population itself, focusing on two nonnative English-speaking (NNES) international students in an English-speaking graduate school in the United States. Through the lens of investment and imagined communities, Chang argued that the students were able to exert their own agency "to fight their academic battle" (p. 228) and selectively invest in areas that would increase their market value in their current and imagined communities.

In the multilingual European context, interest in work on identity and investment has been gathering momentum. Research on English as a lingua franca (Jenkins, 2006) has drawn considerably on Norton's work, while German-speaking European educators have found the relationship between literacy, identity, and investment productive for classroom-based research with youth (Bertschi-Kaufmann \& Rosebrock, 2013). Most recently, in May 2014, an international symposium on the construct of investment was held at the University of Lausanne in Switzerland. The organizers, Chiara Bemporad and Thérèse Jeanneret, saw the symposium as an opportunity "to recontextualize the notion of investment in the field of the francophone didactique des langues and to consider its possible developments, articulating theoretical considerations and empirical analyses from various research contexts" (Bemporad \& Jeanneret, 2014, para. 3) The symposium, which opened with a paper by Norton and Darvin (2014), addressed a wide range of issues with regard to the construct of investment, including the challenges of translating research on investment from English to French (Zeiter \& Bemporad, 2014), the political economy of language investment (Duchêne, 2014), and the relationship between materiality and investment (Dagenais \& Toohey, 2014). A special issue of the journal Langage et Société (Bemporad, forthcoming) will provide highlights of this important symposium and feature the model of investment presented in the next section of this article.

A MODEL OF INVESTMENT FOR THE NEW WORLD ORDER:

IDEOLOGY, CAPITAL, IDENTITY

Norton's study of five immigrant Canadian women in the 1990s captured the concerns of a time when large-scale migrations were changing the political and 
economic landscape of highly industrialized countries. Migration was viewed as a one-way movement from a country of origin to a country of settlement, and the acquisition of the host country's official language was seen as crucial to cultural integration and meaningful employment. By asserting their identity and reframing relations of power, language learners sought to claim the right to speak in the language of power in the host country.

In the past two decades, however, the world has gone through many upheavals. Shifts in the global economic order have led to new relations of power on macro and micro levels, reshaping language ideologies, linguistic capital, and interactions within multilingual and multicultural environments (Blommaert, 2013; Heller, 2011; Kramsch, 2013). Through more affordable travel costs, mobile communication devices, Internet connectivity, and social media, learners are able to traverse transnational spaces (Lam \& Warriner, 2012; Warriner, 2008) and oscillate between online and offline worlds, transforming notions of public and private domains, citizenship, and identity (Darvin, forthcoming; Gee \& Hayes, 2011). Moving fluidly across these unbounded spaces has necessitated a communicative competence that involves the capacity to shift effortlessly from one set of communicative norms to another (Blommaert, 2013). Because of the dynamic nature of these spaces, and the increasing diversity of those who occupy them, the asymmetric distribution of power no longer rests on the simple dichotomy of native speaker and language learner. Beyond inclusion in a target community of speakers or the acquisition of material and symbolic resources, learners are able to participate in a greater variety of spaces in both face-to-face and virtual worlds and assert themselves to varying degrees as legitimate speakers. As social media, SMS, email, and other Web 2.0 functionalities allow them to speak by writing (Cope \& Kalantzis, 2012; Jones \& Hafner, 2012; Warschauer \& Matuchniak, 2010), literacy has become even more essential in being able to claim the right to speak (Janks, 2010; Moje \& Luke, 2009).

Technology has not only reshaped the way we communicate but also enabled new forms of labor and modes of productivity. Together with privatization and deregulation instigated by neoliberal policies, this shifting work landscape has ushered people into more private, isolated spaces. Mechanisms of power become more invisible as the logic of a free market remains to be the postulate of corporate decisions. Through the individualization of labor and the proliferation of precarious employment, exploitation and inequality become even greater (Crompton, 2008). The financial crisis of 2008 has demonstrated quite vividly the polarization wrought by this reality. At the same time, shifts in global economic power, for example, the rise of China and newly industrialized countries, have led to changes in the valuing of languages, consequently transforming language ideologies, which not only shape policy, but also inform the dynamics of multilingual encounters (Bianco, Orton, \& Gao, 2009; Block, Gray, \& Holborow, 2012; Duchêne \& Heller, 2012).

To respond to this current world order, what we propose is a model of investment that is able to reinvigorate the promise of change that foundational poststructuralist theories sought to achieve (Kramsch, 2013) and to lay bare what is becoming increasingly invisible. This impetus requires not only sharpening the 


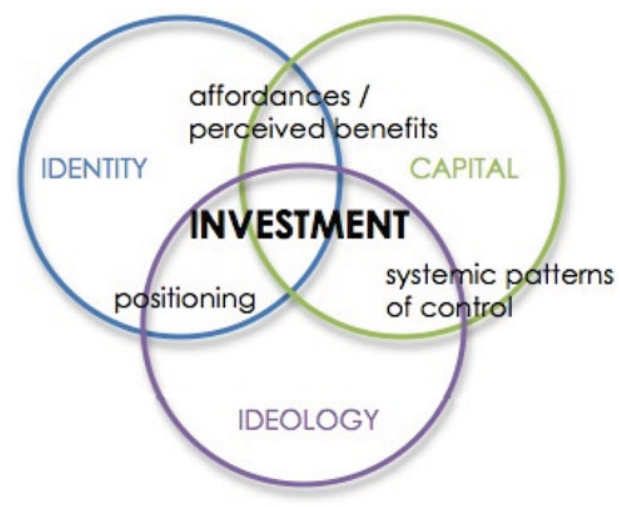

FIGURE 1. (Color online) Darvin and Norton's 2015 Model of Investment.

focus but also widening the lens: to go beyond the microstructures of power in specific communicative events and to investigate the systemic patterns of control that communicative events are indexical of. This dual perspective establishes the link between the situated and the recursive, and it allows us to examine how discrete events evolve into communicative practices. It is by casting a light on the constructed nature of what is held as normative that one can find the interstices that enable critical inquiry. We take the position that the key constructs that will allow us to achieve this task, together with identity, are ideology and capital (see Figure 1). These three constructs are examined in greater depth below. While ideology has been a much contested construct in recent years, it is through an interrogation of ideology that one can examine more closely how power manifests itself materially in the practices of a classroom, workplace, or community; the positioning of interlocutors; and the structuring of habitus. On the other hand, a more fluid conception of capital that recognizes how its value shifts across spaces enables a greater understanding of how learners gain or lose power as they lead increasingly mobile lives.

\section{Ideology}

As globalization accelerates the flow of goods, people, ideas, and resources (Appadurai, 1990), the lived realities of learners have also become more complex and fraught with contradictions. Duchêne, Moyer, and Roberts (2013) point out that while "the discourses of globalization and neoliberalism are ones of 'mobility,' 'flows,' 'flexibility' and 'de-regulation,' many of the practices entailed in globalization are of control and regimentation" (p. 9). It is in what they call "ideological sites" or "sites of control" - public and private institutions, nongovernmental organizations (NGOs), work site spaces-where the management of resources and the legitimization of regulatory systems take place, and mapping out these spaces enables an examination of the "soft, invisible, capillary force" of power (p. 10). A more critical examination of the language acquisition process in this age of mobility must therefore lay bare the systemic patterns of control that have been 
rendered invisible, and to achieve this, De Costa (2010) asserts the need for an ideology-based theoretical framework. He argues that while the use of constructs like "cultural models," "subjectivities," or "positioning" in language learning research do reflect an orientation towards ideology, there is still a need to develop a more comprehensive approach that explicitly calls out ideology and examines the sociopolitical contexts of schools and communities and the shifting values of linguistic capital.

One route scholars have taken to do exactly this is language ideology (Irvine \& Gal, 2009; Kroskrity, 2004; McGroarty, 2008; Woolard \& Schieffelin, 1994), which highlights how language is an ideologically defined social practice. Communicative events, as the interaction of voices from different social positions, are indexical of ideological processes of dominance and contestation. Blommaert (2006) points out that the very identification of specific languages, each with a system of signs and grammatical structures, together with the assemblage of particular speech communities, is itself a powerful language-ideological effect. The valuing of languages, the establishment of language policies, and the construction of ethnolinguistic identities are inscribed by language ideology, and hence any examination of linguistic exchanges is inevitably an extrapolation of ideological forces at work.

While language ideology is an important construct to understand the mechanisms of power in linguistic exchanges, what we wish to employ in this model of investment is a broader construct of ideology, that is, as a normative set of ideas. For Bourdieu (1987), this set of ideas is constructed by symbolic or worldmaking power, "the power to impose and to inculcate principles of construction of reality" (p. 13). Legitimated authority enables the arbitrary to be misrecognized as the natural order. As this order organizes and regulates, it constructs modes of inclusion and exclusion, and learners are positioned in multiple ways before they even speak. As embodied identities inscribed by race, ethnicity, gender, and social class, learners navigate through spaces where they are not only granted or refused the right to speak, but also the right of entry. Examining how ideologies operate, we believe, enables us to dissect not just the dynamics of power within communicative events, but also the structures of power that can prohibit the entry into specific spaces where these events occur. Hence, integrating the construct of ideology in this model of investment allows us to analyze the relation between communicative practices and systemic patterns of control at both micro and macro levels.

Because political and institutional environments operate to transform a particular set of ideas into a dominant way of thinking, Blommaert (2005) defines ideology as "materially mediated ideational phenomena" (p. 164). This understanding of ideology as the collusion of the ideational and the material is akin to Foucault's episteme, which operates within sets of practices and institutional conditions, and Bourdieu's notion of reproduction, which connects institutional educational practice and the construction of legitimate knowledge. Ideology, however, should not be understood as a static, monolithic worldview, but as a complex, layered space where ideational, behavioral, and institutional aspects interact and sometimes 
contradict one another. In this space, dominance and hegemony are processes rather than facts, and the reproduction of determined meanings is concomitant with the performance of innovative practices (Blommaert, 2005). Such a conception has powerful implications for the issues of structure and agency, and it draws attention to the fact that the reproduction of dominant culture is sustained by both coercion and consent.

While habitus is shaped by structures that govern and are perpetuated by ideology, the recognition of ideology as a site of struggle, of competing dominant, residual, and marginal ideas, enables an understanding of identity that has a certain disposition to act and think a certain way, but also has the agency to restructure contexts. Agents act within a spectrum of consent and dissent, and what appears to be consent sometimes may be a matter of hegemonic practices, or orthopraxyperforming hegemonic acts without necessarily subscribing to the ideology that informs them (Blommaert, 2005). Operationalizing this polylithic and porous conception of ideology, we believe, requires referring to ideologies. Constructed and imposed by structures of power and reproduced through hegemonic practices and consent, ideologies are dominant ways of thinking that organize and stabilize societies while simultaneously determining modes of inclusion and exclusion, and the privileging and marginalization of ideas, people, and relations. This pluralized formulation complements our view of identity as multiple and fluid, and of capital shifting values in different contexts. Not only is it more congruent with the new social order of mobility and fluidity, but it also allows a conception of investment that engenders greater agency and capacity for resistance.

\section{Capital}

Through this more nuanced understanding of ideology, we can also examine more closely the nature of capital, its role in investment, and the ways it can serve as a tool of both social reproduction and transformation. For Bourdieu (1986), capital is power and it extends from the material/economic to the cultural and social: Economic capital refers to wealth, property, and income; cultural capital refers to knowledge, educational credentials, and appreciation of specific cultural forms; and social capital refers to connections to networks of power. The value of these forms of capital is determined by ideological structures, but it is continually negotiated in different fields or sites of struggle.

The structure of the distribution of the different types and subtypes of capital at a given moment in time represents the immanent structure of the social world, i.e. the set of constraints, inscribed in the very reality of that world, which governs its functioning in a durable way, determining the chances of success and practices. (Bourdieu, 1986, p. 46)

Agents are positioned in the social space based on the volume, composition, and trajectory of their capital. As the rules of the game vary in different fields and continually evolve, the value of one's capital also shifts as it travels across time and space. The form the different types of capital take "once they are perceived and 
recognized as legitimate" (Bourdieu, 1987, p. 4) is what Bourdieu calls symbolic capital, and it is through this conceptualization that we can understand how capital itself is fluid and dynamic, subject to-but not completely constrained by-the dominant ideologies of specific groups or fields.

Symbolic capital is particularly relevant in understanding investment in this new world order. As learners operate across transnational contexts and flit in and out of online and offline spaces, this construct points out two significant ideas: First, learners do enter these spaces equipped with capital-for example, their own material resources, linguistic skills, and social networks - and are not empty vessels. Second, occupying new spaces involves not only acquiring new material and symbolic resources but also using the capital that learners already possess as affordances and transforming this capital into something that is regarded as valuable in new contexts. This conversion is always a site of struggle, given that what may be valued in one place may be radically devalued in another. When people move across borders, for instance, the linguistic capital they bring with them is subject to what Blommaert (2010) calls different orders of indexicality, that is, their styles and registers are measured against a value system that reflects the biases and assumptions of the larger sociocultural context. Functions that are valid in local settings are imposed on the ways of speaking of transnationals, and discourses only gain value when others grant them value. These two points compel teachers to reflect on the importance of treating the linguistic and cultural capital of learners as affordances rather than constraints and to question and reevaluate the taken-for-granted value systems they use to assess this capital.

\section{Identity}

The conception of identity in this model still aligns well with the theoretical underpinnings of Norton's (2013) work, which defines identity as multiple, a site of struggle, and continually changing over time and space. What this model seeks to do is to elucidate further that identity is a struggle of habitus and desire, of competing ideologies and imagined identities. Governed by different ideologies and possessing varying levels of capital, learners position themselves and are positioned by others in different contexts.

This sense of one's place is at the same time a sense of the place of others, and, together with the affinities of habitus experienced in the form of personal attraction or revulsion, is at the root of all processes of cooptation, friendship, love, association, etc., and thereby provides the principle of all durable alliances and connections. (Bourdieu, 1987, p. 5)

As an internalized system shaped by ideology, habitus is the system by which people make sense of the world. It configures in learners an idea of their "rightful" place in society and predisposes them to do what they believe is expected of them and to develop relations that are deemed appropriate. It is "a system of durable, transposable dispositions ... principles which generate and organize practices and representations" (Bourdieu, 1990, p. 53). As disposition, habitus provides a 
conceptual understanding of what is reasonable and possible and a tendency to think and act in ways that correspond with a prevailing ideology. At the same time, also because of dominant ideologies, learners are positioned in certain ways by virtue of their gender, race, ethnicity, social class, or sexual orientation. How learners are perceived by others is shaped by prevailing notions of what it means to be man or woman, Black or White, middle class or working class in a specific society. In the same way, also because of habitus, learners in turn position others and accord or refuse them power. Indeed, it is through such mechanisms that power secures itself, and it is through a deliberate and critical awareness of how power operates that ideologies can be challenged (Norton, 2013).

While the concepts of "positioning" or "subject position" are metonymic of the imposition of power, they can also allow learners to regard themselves as "choosing subjects" (Davies \& Harré, 1990), who can rethink this "place" that has been filled and internalized. Although Bourdieu viewed habitus as a set of dispositions that are durable and shaped by history, he recognized that "guided by one's sympathies and antipathies, affections and aversions, tastes and distastes, one makes for oneself an environment in which one feels 'at home' and in which one can achieve that fulfillment of one's desire to be which one identifies with happiness" (Bourdieu, 2000 , p. 150). What learners desire can also be shaped by habitus; however, it is through desire that learners are compelled to act and exercise their agency. Whether it is because learners want to be part of a country or a peer group, to seek romance, or to achieve financial security, learners invest because there is something that they want for themselves - it is part of the structure of desire, as comprehensively theorized by Motha and Lin (2014). Further, it is in the realm of the imagination-what Norton has called imagined identities (Norton, 2013; Kanno \& Norton, 2003) that learners are able to express this desire. Imagination allows learners to re-envision how things are as how they want them to be.

\section{THE MODEL IN PRAXIS}

As presented above, the model we propose responds to the demands and realities of the new world order, locating investment at the intersection of identity, capital, and ideology. Recognizing how power flows in different directions through these contiguous spaces, learners operating in different fields perform multiple identities. Their habitus, shaped by prevailing ideologies, predisposes them to think and act in certain ways, but it is through desire and imagination that they are able to invest in practices that can transform their lives. In this model, learners invest in particular practices not only because they desire specific material or symbolic benefits, but also because they recognize that the capital they possess can serve as affordances to their learning. The valuing of their capital is an affirmation of their identity, a legitimation of their rightful place in different learning contexts. At the same time, because of the pull of ideology, the capital they possess may not be accorded symbolic value by structures of power, or the capital they desire becomes difficult to attain because of systemic patterns of control. Ideology shapes 
these institutional patterns and practices, and it structures habitus. It is reflected not only in the way learners are positioned in specific contexts, but also how learners position themselves and others. The desire to be part of an imagined community or to take on an imagined identity enables the learner to gain from or to resist these positions. Recognizing that they have the agency to assert their own identities, learners are able to negotiate symbolic capital, reframe relations of power, and challenge normative ways of thinking, in order to claim the right to speak.

Built around these ideas, this model extends the question, "To what extent are learners invested in the language and literacy practices of their classrooms and communities?" to include the following:

1. How invested are learners in their present and imagined identities? In what ways are they positioned by others, and how do they, in turn, position interlocutors in ways that grant or refuse power? How can learners gain from or resist these positions?

2. What do learners perceive as benefits of investment, and how can the capital they possess serve as affordances for learning?

3. What systemic patterns of control (policies, codes, institutions) make it difficult to invest and acquire certain capital? How have prevailing ideologies structured learners' habitus and predisposed them to certain ways of thinking?

What we hope to achieve through the framing of these questions is to create a space in which learners are not by default marginalized or resistant, but where they have an agentive capacity to evaluate and negotiate the constraints and opportunities of their social location. While there are structures that indeed subjugate learners and constrain their investment, this model draws attention to how learners may paradoxically contribute to their own subjugation through the performance of hegemonic practices. By raising questions about their own ways of thinking of the status quo, it seeks to enable more opportunities for reflexivity and dissent, so that learners may not only participate in but also transform the multiple spaces of their life worlds. It recognizes that as the spaces they occupy become more deterritorialized, dynamic, and diverse, it becomes easier for them to participate in or retreat from specific contexts. This freedom of movement and the decentralization of spaces in some way diffuse and even reconfigure power, allowing learners to choose not only to invest but also to purposefully divest from particular language and literary practices.

As today's learners pursue more mobile lives because of technology, the terrain that they must navigate and negotiate has become more complex. Real and virtual spaces require different literacies and strategies for them to gain entry and participate fully in these spaces. Hence, the learner needs to develop a more durable sense of the communicative "game," or what Bourdieu (1986) calls a sens pratique, or practical sense. This sens pratique is a practical mastery of the logic or immanent necessity of a game, which one gains through experiencing the game. Kramsch and Whiteside (2008) drew from sens pratique to develop the notion of symbolic competence, which focuses on individual repertoires in multilingual settings and refers to the shifting of codes to reframe power in specific 
communicative events. While symbolic competence focuses on the play of linguistic codes as people move from one place to another, Pennycook and Otsuji (2014), on the other hand, talk about metrolingual multitasking, which involves "the dynamic relations between semiotic resources, activities, artefacts, and space" (p. 162). They recognize that speakers engage in multiple, fast-paced, sometimes simultaneous activities, where both linguistic and nonlinguistic resources are deployed. As speakers navigate through various spaces, they activate spatial repertoires: "the available and sedimented resources that derive from the repeated language practices of the people involved in the sets of activities related to particular places" (p. 166). This construct conjoins the repertoires that individuals develop through their lived experiences and those that are constituted by the linguistic resources available in different spaces. In both cases, these repertoires are regularized through repetition, in the same way that practical sense is developed through practice and serves very practical purposes.

In contrast to symbolic competence and metrolingual multitasking, the practical sense we advocate for here as a necessary component of language learning is one that enables learners to negotiate the mobilities and complexities of the digital age. As learners traverse simultaneous online and offline, local and translocal spaces, this practical sense enables learners to (a) master the rules, norms, genres, and multimodal features specific to different communicative contexts; (b) seamlessly shift codes, practices, and strategies while moving across spaces; and (c) use linguistic and nonlinguistic resources to gain access to, challenge, and transform these spaces. By repeatedly performing multiple repertoires and shifting strategies as required, learners are able to sharpen this competence until it becomes practical sense.

\section{Two case studies}

To illustrate how this model of investment can be used to examine the needs of diverse learners in the digital age, we turn to two case studies of learners of contrasting geographical and social locations: Henrietta in Uganda and Ayrton in Canada.

Henrietta is an 18-year-old female student who participated in a study on the use of digital resources for HIV/AIDS education and enhanced language development (Norton et al., 2011). She lives in a rural village in Uganda that has limited electricity and no running water, with a per-capita income of less than $\$ 1$ a day. The researchers brought Henrietta and her peers, who had neither the funds nor the digital literacy, to an Internet café in a neighboring town to research HIV/AIDS. By working on this concrete task, the learners were able to develop the skills of navigating the web to find the information they needed. During data collection, Henrietta explained why she thought digital literacy was important and what she had learned from the course:

I learnt how to use a computer/introduction to the computer. I learnt to access information on the Internet. I learnt how people can communicate through Internet. I 
learnt how people get information from the Internet. I learnt the methods of preventing HIV/AIDS and all about AIDS.

She elaborated as follows, "My main interest in learning more about computers is to know how they use Internet, to communicate to people in the outside countries." She stated her belief that knowledge gained through the Internet would enhance self-knowledge, as she would "learn more about [her]self through sharing view with Canadian people." Her fervent desire was to "join the group of knowledgeable people in the world," what another student, Jenenie, called becoming "mentally modernized." It is Henrietta's investment in this imagined identity that will determine to what extent she will invest in the digital literacy practices of the course.

To develop her literacy and to continually engage in these transnational conversations may prove to be a huge challenge for Henrietta, however. Not only is her own economic capital limited, but also the technological infrastructure of her local context is poorly resourced. In this case, both her own social location and the economic position of rural Uganda constrain access to the technology necessary for Henrietta to master literacies relevant to the knowledge economy and develop a sens pratique. While she may be driven by a strong desire to learn more about computers and to connect with other people, her social location makes it very difficult for her to enter these new spaces of socialization. Even though her desire to engage in transnational conversations can be seen as a way to increase her social capital, how this perceived benefit will prove to be of durable and controvertible value, that is, recognized as symbolic capital in specific fields, is yet to be seen.

Because of the discourses of globalization and technology that construct her own conceptions of what is valuable or not, Henrietta positions herself as inadequate, as one who is not sufficiently "knowledgeable." This hegemonic view reproduces ideologies where the global is privileged over the local, and the global North is seen as more knowledgeable than the global South. As she seeks to gain access to affordances of learning like devices and books, systemic patterns of control will also determine this access: the allocation of technology budgets to local schools, the development of connectivity infrastructure in rural Uganda, and business processes that impact the affordability of devices. Ideologies that privilege urban versus rural, middle versus lower class, or male versus female will also position Henrietta further and shape her capacity to gain certain affordances. In terms of linguistic capital, although she speaks English, which has become the de facto lingua franca of the Internet, her access to valued forms of English is limited. Indeed, what she finds particularly appealing about the Internet is that it gives her the opportunity to "understand more about English language." As she noted, "I got communication. I have learnt the English language because the English in Internet has been very create and it has arranged properly." How other interlocutors will position her as a teenage girl from rural Uganda will shape the dynamics of their interaction, and her linguistic capital will be measured against their own orders of 
indexicality, as described with reference to Blommaert's young Tanzanian friend, Victoria (Blommaert, 2003).

To contrast with Henrietta's investment, we now turn to Ayrton, a 16-year-old Filipino male who lives in a wealthy neighborhood of Vancouver, and whose family emigrated through the Investor Class, in which migrants need to have a net worth of at least CAN\$1.6 million. He participated in a study that examined the digital literacies in home settings of learners with contrasting socioeconomic backgrounds (Darvin \& Norton, 2014a). Ayrton's father is an entrepreneur who continues to manage multiple businesses in the Philippines remotely, and his mother is a homemaker. Each member of the family owns at least two digital devices, including a phone, a laptop, and/or a tablet. Connectivity is never an issue as they move seamlessly from Wi-Fi at home or school to LTE or 3G in public spaces. Whether it's for doing schoolwork, engaging in social media, or getting news updates, technology has been completely integrated into Ayrton's daily life. He is visibly adept in it, multitasking with great ease, while jumping from one application to another. The social position of Ayrton as part of a privileged class in a highly industrialized country has made technology natural, providing him with all the affordances of learning. His parents and older siblings, who are all skilled users, serve as digital literacy role models and shape his conception of what technology is for.

Asked about what technology means to him, Ayrton described it as a bridge "that connects me to people as far as Orlando in the United States or people back in the Philippines." Because his privileged position has allowed him to travel extensively, he does not just seek to connect to a generic "group of knowledgeable people in the world," but he refers to a concrete network of people he knows in specific geographical locations and who have access to similar technologies. This social capital is gained by the mobility afforded by his social position and itself becomes a form of capital. His access to resources allows him to already claim the identity of "knowledgeable people," and the social future and identities he imagines are boundless: "With how the world is just connected and how information is at your fingertips, you can be anyone or anything you want to be and it's just right there." Growing up with an abundance of resources has developed in him a strong sense of agency. He is able to claim ownership of a future that he imagines for himself and that he believes is within reach.

Indeed, his possession of economic, cultural, and social capital and his identity as a member of a highly industrialized country allow him to position himself as a legitimate participant and contributor in the different affinity spaces he occupies online. Sharing his father's entrepreneurial spirit, he signed up for an online course on currency trading, where he engages in online discussions with adult professionals from a global network. By carefully curating his social media profiles and shifting language registers as necessary, he is able to conceal his age and express opinions about market trends and opportunities, which are valued by others. Through this sens pratique, he is able to assert his place as a legitimate speaker in these spaces, and gain even greater knowledge valued in capitalist contexts. Although it is his parents who paid a premium for this course, he describes enrolling in it as "one of the greatest investments of [his] life." 
In his use of digital resources, Ayrton reflects a very strong entrepreneurial orientation, role-modeled by his father. This identification completely aligns with the neoliberal ideology that regards the individual as homo economicus or "an entrepreneur of one's self' (Foucault, 2008), who is held completely accountable for his or her own economic success or failure. In contrast to Henrietta's aspiration to communicate with other people, Ayrton's investment in the imagined identity of a currency trader is much more concrete. Its realization comes with more tangible measurements of success and translates into the accumulation of economic capital. While Henrietta's interest in the digital is more friendship driven, a desire to connect with the rest of the world-an aspiration that does not necessarily translate into greater social mobility, Ayrton's use of technology is primarily interest driven-gathering information that allows him to pursue more profitable ventures. In this case, the habitus of these two learners develops divergent digital tastes and literacies, which leads to the acquisition of varying levels of material and symbolic benefits.

\section{CONCLUSION}

In the new world order characterized by mobility, fluidity, and diversity, operating within the paradox of flow and control, identity has been impacted by more complex issues of structure and agency. In the digital age, the spaces of language learning continue to multiply and evolve with distinct and increasingly invisible structures of power with concomitant implications for conceptions of "good" language learning (Cohen \& Griffiths, in press) and "learner strategies" (Oxford et al., 2014). To respond to this rapid transformation, we need a model of investment that not only examines the microstructures of power in communicative events but also investigates the systemic patterns of control that recurring communicative practices are indexical of. As people move in and out of increasingly fragmented spaces, a sens pratique or practical sense that responds to the complexities of the digital age enables learners with varying forms of capital not only to navigate these spaces but also to potentially transform them as well.

A more macro examination allows us to locate learners in this complex web of power and to recognize how these ideological sites shape disposition, social position, and the conditions in which learners can claim the right to speak. At the same time, we recognize that learners have agency and that they have the capacity to invest in learning that allows them not only to acquire material and symbolic resources in a way that reproduces the status quo, but also to dissect, question, and sometimes resist dominant practices and ways of thinking that have become systemic within different fields. Our hope is that this organic model of investment, designed to respond to more contemporary challenges and opportunities, will contribute to the rich discussion and vibrant research on identity and language learning and teaching in the field of applied linguistics. 


\section{Ron Darvin, a Vanier Doctoral Scholar, acknowledges the generous support of the Vanier Canada Graduate Scholarships Program.}

\section{ANNOTATED BIBLIOGRAPHY}

Blommaert, J. (2010). The sociolinguistics of globalization. Cambridge, UK: Cambridge University Press.

This important book examines the impact of globalization on linguistic practices, as they are negotiated across boundaries and within different communities. The book demonstrates how people and languages are positioned with reference to different orders of indexicality that define norms of language use and social expectations. Drawing on case studies from diverse regions of the world, Blommaert provides a theoretically grounded and sophisticated analysis of how increased mobility has led to greater linguistic inequalities.

Bourdieu, P. (1991). Language and symbolic power. Cambridge, MA: Harvard University Press.

In this seminal text, Bourdieu provides a comprehensive theoretical framework that utilizes economic metaphors to examine how linguistic exchanges express relations of power. He addresses the ways in which symbolic power is circulated and reproduced through ideological systems, and how social structure is present in every linguistic interaction. Recognizing that individuals possess varying levels of capital and occupy different positions, this philosophical treatise demonstrates that the value of a person's utterances signal social and political conditions.

Duchêne, A., \& Heller, M. (eds.). (2012). Language in late capitalism: Pride and profit (Vol. 1). Oxon, UK: Routledge.

Analyzing the political economic changes in the globalized new economy, this exciting collection of articles uses the tropes of pride and profit to examine how language has been instrumental in constructing modern nation-states and ideologies, while increasingly being recognized as a technical skill and commodity. As these two roles are continually reconfigured in late capitalism, this book provides powerful examples of how this tension is negotiated in different parts of the world.

Norton, B. (2013). Identity and language learning: Extending the conversation (2nd ed.). Bristol, UK: Multilingual Matters.

This second edition of Norton's highly cited 2000 book reframes the constructs of identity and investment in light of the ways they have been taken up by diverse scholars in recent years. Integrating a more global perspective, which includes a discussion of identity and language teaching, it also explores how the transformation of the social world through the digital has spurred new, exciting scholarship on language and identity. The Afterword by Claire Kramsch offers an insightful analysis of Norton's key ideas.

Preece, S. (ed.). (forthcoming). Routledge handbook of language and identity. Oxon, UK: Routledge.

This timely handbook provides a comprehensive overview of contemporary research on language and identity in applied linguistics and language education. It offers a historical perspective of how the construct of identity has shifted over time, and the various theoretical perspectives that frame and enrich research on language and identity. Incorporating different case studies from a variety of contexts, this collection also forecasts future issues and developments that will be vital in generating further scholarship on language and identity.

\section{REFERENCES}

Andema, S. (2014). Promoting digital literacy in African education: ICT innovations in a Ugandan primary teachers' college (Doctoral dissertation). Retrieved from http://elk.library.ubc.ca/handle/2429/48513. 
Anya, U. (forthcoming). Speaking blackness in Brazil: Racialized identities in second language learning. New York: Routledge.

Appadurai, A. (1990). Disjuncture and difference in the global cultural economy. Theory, Culture and Society, 7(2-3), 295-310.

Arkoudis, S., \& Davison, C. (guest eds.) (2008). Chinese students: Perspectives on their social, cognitive, and linguistic investment in English medium interaction. Journal of Asian Pacific Communication, 18(1), 3-8.

Bearse, C., \& de Jong, E. J. (2008). Cultural and linguistic investment: Adolescents in a secondary two-way immersion program. Equity \& Excellence in Education, 41(3), 325-340.

Bemporad, C., \& Jeanneret, T. (2014). Symposium program for Dialogues autour de la notion d'investissement dans l'appropriation langagiere, Lausanne, Switzerland, May 2014.

Bemporad, C. (ed). (forthcoming). Language investment, une notion majeure pour saisir les dynamiques sociales de l'appropriation langagière. Langage et Société.

Bertschi-Kaufmann, A. \& Rosebrock, C. (eds.). (2013). Literalität erfassen: bildungspolitisch, kulturell, individuell. Weinheim und München: Juventa.

Bianco, J. L., Orton, J., \& Gao, Y. (eds.). (2009). China and English: Globalisation and the dilemmas of identity. Bristol, UK: Multilingual Matters.

Block, D. (2007). The rise of identity in SLA research, post Firth and Wagner (1997). The Modern Language Journal, 91(1), 863-876.

Block, D. (2014). Social class and applied linguistics. Oxon, UK: Routledge.

Block, D., Gray, J., \& Holborow, M. (2012). Neoliberalism and applied linguistics. Oxon, UK: Routledge.

Blommaert, J. (2003). Commentary: A sociolinguistics of globalization. Journal of Sociolinguistics, 7(4), 607-623.

Blommaert, J. (2005). Discourse: A critical introduction. Cambridge, UK: Cambridge University Press.

Blommaert, J. (2006). Language ideology. In E. K. Brown (ed.), Encyclopedia of Language and Linguistics (pp. 510-522). Oxford: Elsevier.

Blommaert, J. (2010). The sociolinguistics of globalization. Cambridge, UK: Cambridge University Press.

Blommaert, J. (2013). Ethnography, superdiversity and linguistic landscapes: Chronicles of Complexity. Bristol, UK: Multilingual Matters.

Bourdieu, P. (1977). The economics of linguistic exchanges. Social Sciences Information, 16(6), 645668.

Bourdieu, P. (1984). Distinction: A social critique of the judgement of taste. Cambridge, MA: Harvard University Press.

Bourdieu, P. (1986). The forms of capital. In J. F. Richardson (ed.), Handbook of theory and research for the sociology of education (pp. 241-58). New York, NY: Greenwood Press.

Bourdieu, P. (1987). What makes a social class? On the theoretical and practical existence of groups. Berkeley Journal of Sociology, 32, 1-17.

Bourdieu, P. (1990). The logic of practice. Stanford, CA: Stanford University Press

Bourdieu, P. (1991). Language and symbolic power. Cambridge, MA: Harvard University Press.

Bourdieu, P. (2000). Pascalian meditations. Stanford, CA: Stanford University Press.

Carazzai, M. R. (2013). The process of identity (re)construction of six Brazilian language learners: A poststructuralist ethnographic study (Doctoral dissertation). Retrieved from https://repositorio.ufsc.br/handle/123456789/105150

Chang, Y. J. (2011). Picking one's battles: NNES doctoral students' imagined communities and selections of investment. Journal of Language, Identity and Education, 10(4), 213-230.

Clark, J. B. (2009). Multilingualism, citizenship, and identity: Voices of youth and symbolic investments in an urban, globalized world. London, UK: Bloomsbury.

Cohen, A., \& Griffiths, C. (in press). Revisiting LLS research 40 years later. TESOL Quarterly.

Cope, B., \& Kalantzis, M. (2012). Literacies. New York, NY: Cambridge University Press.

Crompton, R. (2008). Class and stratification (3rd ed.). Cambridge, UK: Polity.

Cummins, J. (2006). Identity texts: The imaginative construction of self through multiliteracies pedagogy. In O. Garcia, T. Skutnabb-Kangas, \& M. Torres-Guman (eds.), Imagining multilingual schools: Languages in education and glocalization (pp. 51-68). Clevedon, UK: Multilingual Matters.

Cummins, J., \& Early, M. (eds.) (2010). Identity texts: The collaborative creation of power in multilingual schools. Staffordshire, UK: Trentham. 
Dagenais, D., \& Toohey, K. (2014). Accounting for materiality in discussions of investment. Paper presented at the Dialogues autour de la notion d'investissement dans l'appropriation langagiere, Lausanne, Switzerland, May 2014.

Darvin, R. (forthcoming). Language and identity in the digital age. In S. Preece (ed.), Routledge handbook of language and identity. Oxon, UK: Routledge.

Darvin, R., \& Norton, B. (2014a). Social class, identity, and migrant students. Journal of Language, Identity and Education, 13(2), 111-117.

Darvin, R., \& Norton, B. (2014b). Transnational identity and migrant language learners: The promise of digital storytelling. Education Matters: The Journal of Teaching and Learning, 2(1), 55-66.

Davies, B., \& Harré, R. (1990). Positioning: The discursive production of selves. Journal for the Theory of Social Behaviour, 20(1), 43-63.

De Costa, P. I. (2010). Reconceptualizing language, language learning, and the adolescent immigrant language learner in the age of postmodern globalization. Language and Linguistics Compass, 4(9), 769-781.

De Costa, P. I., \& Norton, B. (forthcoming). Identity in language learning and teaching: Research agendas for the future. In Preece, S. (ed.) The Routledge handbook of language and identity. Oxon, UK: Routledge

Dörnyei, Z., \& Ushioda, E. (eds.). (2009). Motivation, language identity and the L2 self. Bristol, UK: Multilingual Matters.

Duchêne, A. (2014). Towards a political economy of language investment. Paper presented at the Dialogues autour de la notion d'investissement dans l'appropriation langagiere, Lausanne, Switzerland, May 2014.

Duchêne, A., \& Heller, M. (eds.). (2012). Language in late capitalism: Pride and profit (Vol. 1). Oxon, UK: Routledge.

Duchêne, A., Moyer, M., \& Roberts, C. (eds.). (2013). Language, migration and social inequalities: $a$ critical sociolinguistic perspective on institutions and work. Bristol, UK: Multilingual Matters.

Early, M., \& Norton, B. (2014). Revisiting English as medium of instruction in rural African classrooms. Journal of Multilingual and Multicultural Development, 35(7), 1-18.

Foucault, M. (2008). The birth of biopolitics (G. Burchell, Trans.). London, UK: Palgrave Macmillan.

Gao, X., Cheng, H., \& Kelly, P. (2008). Supplementing an uncertain investment? Mainland Chinese students practising English together in Hong Kong. Journal of Asian Pacific Communication, 18(1), 9-29.

Gee, J. P., \& Hayes, E. R. (2011). Language and learning in the digital age, Oxon, UK: Routledge.

$\mathrm{Gu}, \mathrm{M}$. (2008). Identity construction and investment transformation: College students from non-urban areas in China. Journal of Asian Pacific Communication, 18(1), 49-70.

Haneda, M. (2005). Investing in foreign-language writing: A study of two multicultural learners. Journal of Language, Identity, and Education, 4(4), 269-290.

Heller, M. (2011). Paths to post-nationalism: A critical ethnography of language and identity, Oxford University Press, Oxford.

Higgins, C. (Ed.). (2011). Identity formation in globalizing contexts: Language learning in the new millennium (Vol. 1). Berlin, Germany: Walter de Gruyter.

Irvine, J. T., \& Gal, S. (2009). Language ideology and linguistic differentiation. In A. Duranti (ed.), Linguistic anthropology: A reader. Malden, MA: Wiley-Blackwell.

Janks, H. (2010). Literacy and power. New York, NY: Routledge

Jenkins, J. (2006). Current perspectives on teaching world Englishes and English as a lingua franca. TESOL Quarterly, 40(1), 157-181.

Jones, R. H., \& Hafner, C. A. (2012). Understanding digital literacies: A practical introduction. Oxon, UK: Routledge.

Kamada, L. (2010). Hybrid identities and adolescent girls. Bristol, UK: Multilingual Matters.

Kanno, Y., \& Norton, B. (2003). Imagined communities and educational possibilities: Introduction. Journal of Language, Identity, and Education, 2(4), 241-249.

Kramsch, C. J. (2009). The multilingual subject: What foreign language learners say about their experience and why it matters. Oxford, UK: Oxford University Press.

Kramsch, C. J. (2013). Afterword. In B. Norton, Identity and language learning: Extending the conversation (2nd ed., pp. 192-201). Bristol, UK: Multilingual Matters.

Kramsch, C., \& Whiteside, A. (2008). Language ecology in multilingual settings. Towards a theory of symbolic competence. Applied Linguistics, 29(4), 645-671.

Kroskrity, P. V. (2004). Language ideologies. In A. Duranti (ed.), A companion to linguistic anthropology (pp. 496-517). Malden, MA: Blackwell. 
Lam, E., \& Warriner, D. (2012). Transnationalism and literacy: Investigating the mobility of people, languages, texts, and practices in contexts of migration. Reading Research Quarterly, 47(2), 191215.

Mastrella-de-Andrade, M., \& Norton, B. (2011). Querer é poder? Motivação, identidade e aprendizagem de língua estrangeira. In M. R. Mastrella-De-Andrade (org.), Afetividade e Emoções no ensino/aprendizagem de línguas: múltiplos olhares (pp. 89-114). Campinas, Brazil: Pontes Editores.

McGroarty, M. (2008). The political matrix of linguistic ideologies. In B. Spolsky \& F. Hult (eds.), Handbook of educational linguistics (pp. 98-112). Malden, MA: Blackwell.

McKay, S. L., \& Wong, S. L. C. (1996). Multiple discourses, multiple identities: Investment and agency in second-language learning among Chinese adolescent immigrant students. Harvard Educational Review, 66(3), 577-609.

Menard-Warwick, J. (2009). Gendered identities and immigrant language learning. Bristol, UK: Multilingual Matters.

Mercer, S., \& Williams, M. (eds.). (2014). Multiple perspectives on the self in SLA (Vol. 73). Bristol, UK: Multilingual Matters.

Miller, E., \& Kubota, R. (2013). Second language identity construction. In J. Herschensohn \& M. Young-Scholten (eds.), The Cambridge handbook of second language acquisition (pp. 230-250). New York, NY: Cambridge University Press.

Moje, E., \& Luke, A. (2009). Literacy and identity: Examining the metaphors in history and contemporary research. Reading Research Quarterly, 44(4), 415-437.

Motha, S., \& Lin, A. (2014). "Non-coercive rearrangements": Theorizing desire in TESOL. TESOL Quarterly, 48(2), 331-359.

Murray, G., Gao, X., \& Lamb, T. (2011). Identity, motivation and autonomy. Bristol, UK: Multilingual Matters.

Mutonyi, H., \& Norton, B. (2007). ICT on the margins: Lessons for Ugandan education. Language and Education, 21(3), 264-270.

Norton, B. (2000). Identity and language learning: Gender, ethnicity and educational change. Essex: Pearson.

Norton, B. (2013). Identity and language learning: Extending the conversation (2nd ed.). Bristol, UK: Multilingual Matters.

Norton, B., \& Darvin, R. (2014). Towards a model of investment in language learning: The intersection of identity, capital, and ideology. Paper presented at the Dialogues autour de la notion d'investissement dans l'appropriation langagiere, Lausanne, Switzerland, May 2014.

Norton, B., \& Early, M. (2011). Researcher identity, narrative inquiry, and language teaching research. TESOL Quarterly, 45(3), 415-439.

Norton, B., \& Gao, Y. (2008). Identity, investment, and Chinese learners of English. Journal of Asian Pacific Communication, 18(1), 109-120.

Norton, B., Jones, S., \& Ahimbisibwe, D. (2011). Learning about HIV/AIDS in Uganda: Digital resources and language learner identities. Canadian Modern Language Review/La Revue Canadienne des Langues Vivantes, 67(4), 568-589.

Norton, B., \& McKinney, C. (2011). An identity approach to second language acquisition. In D. Atkinson (ed)., Alternative approaches to second language acquisition (pp. 73-94). New York, NY: Routledge.

Norton, B., \& Toohey, K. (2011). Identity, language learning, and social change. Language Teaching, 44(4), 412-446.

Norton, B., \& Williams, C. J. (2012). Digital identities, student investments and eGranary as a placed resource. Language and Education, 26(4), 315-329.

Norton Peirce, B. (1995). Social identity, investment, and language learning. TESOL Quarterly, 29(1), 9-31.

Ollerhead, S. (2012). "Passivity" or "Potential"? Teacher responses to learner identity in the low-level ESL classroom. Literacy and Numeracy Studies, 20(1), 1-13.

Ortega, L. (2009). Understanding second language acquisition. Oxford, UK: Routledge.

Oxford, R. L., Griffiths, C., Longhini, A., Cohen, A. D., Macaro, E., \& Harris, V. (2014). Experts' personal metaphors and similes about language learning strategies. System, 43, 11-29.

Pavlenko, A., \& Norton, B. (2007). Imagined communities, identity, and English language learning. In J. Cummins \& C. Davison (eds.), International handbook of English language teaching (pp. 669-680). New York, NY: Springer. 
Pennycook, A., \& Otsuji, E. (2014). Metrolingual multitasking and spatial repertoires: "Pizza mo two minutes coming." Journal of Sociolinguistics, 18(2), 161-184.

Pittaway, D. S. (2004). Investment and second language acquisition. Critical Inquiry in Language Studies, 1(4), 203-218.

Potowski, K. (2004). Student Spanish use and investment in a dual immersion classroom: Implications for second language acquisition and heritage language maintenance. The Modern Language Journal, 88(1), 75-101.

Preece, S. (ed.). (forthcoming). Routledge handbook of language and identity. Oxon, UK: Routledge.

Reeves, J. (2009). Teacher investment in learner identity. Teaching and Teacher Education, 25(1), 34-41.

Sanches Silva, J. F. (2013). The construction of English teacher identity in Brazil: A study in Mato Grosso do Sul (Doctoral dissertation). Retrieved from https://repositorio.ufsc.br/handle/ $123456789 / 105151$

Skilton-Sylvester, E. (2002). Should I stay or should I go? Investigating Cambodian women's participation and investment in adult ESL programs. Adult Education Quarterly, 53(1), 9-26.

Swain, M., \& Deters, P. (2007). "New" mainstream SLA theory: Expanded and enriched. The Modern Language Journal, 91(s1), 820-836.

Tembe, J., \& Norton, B. (2008). Promoting local languages in Ugandan primary schools: The community as stakeholder. Canadian Modern Language Review, 65(1), 33-60.

Trent, J. (2008). Promoting investment by Chinese learners in classroom discourse Integrating content and language in the undergraduate classroom. Journal of Asian Pacific Communication, 18(1), 3048.

Warriner, D. S. (2008). Transnational literacies: Immigration, language learning, and identity. Linguistics and Education, 18(3), 201-214.

Warschauer, M., \& Matuchniak, T. (2010). New technology and digital worlds: Analyzing evidence of equity in access, use, and outcomes. Review of Research in Education, 34(1), 179-225.

Weedon, C. (1987). Feminist practice and poststructuralist theory. Oxford, UK: Basil Blackwell.

Woolard, K. A., \& Schieffelin, B. B. (1994). Language ideology. Annual Review of Anthropology, 23(1), 55-82.

Zeiter, A., \& Bemporad, C. (2014). Traduire Bonny Norton en francais: comment articuler differentes traditions de recherche. Paper presented at the Dialogues autour de la notion d'investissement dans l'appropriation langagiere, Lausanne, Switzerland, May 2014. 